\title{
ПРОБЛЕМА РАЗВИТИЯ ДОКТРИНЫ «СНЯТИЯ КОРПОРАТИВНОЙ ВУАЛИ» В РОССИЙСКОМ ПРАВЕ
}

\section{THE PROBLEM OF THE DEVELOPMENT OF THE DOCTRINE OF "REMOVING THE CORPORATE VEIL" IN RUSSIAN LAW}

\section{A. Kuznetsov}

Summary. The article deals with the problem of applying the doctrine of "removing the corporate veil". Indicates that there is no consensus on the terms and scope of the "corporate veil removal" doctrine. The author suggests the main conditions for the application of the legal mechanism for bringing controlling persons to responsibility in civil law. The directions of the doctrine application are suggested, with the justification of the application of the mechanism of corporate cover removal in the framework of ordinary civil law disputes. The ways and methods of solving the problem of the lack of uniformity in the application of this legal mechanism are indicated, including the proposal to fix the conditions for the application of the doctrine in the framework of civil legislation.

Keywords: the doctrine of "removing the corporate veil", responsibility, controlling persons, lender, abuse of law.

\author{
Кузнечов Андрей Вячеславович \\ Аспирант, ФГБОУ ВО «Байкальский государственный \\ университет", г. Иркутск \\ kuznec3194@gmail.com
}

Аннотация. В статье рассматривается проблема применения доктрины «снятия корпоративной вуали». Указывает на отсутствие единого мнения В отношении условий и области применения доктрины «снятия корпоративной вуали». Автором предлагаются основные условия применения правового механизма привлечения контролирующих лиц к ответственности в гражданском праве. Предлагаются направления применения доктрины, с обоснованием применения механизма снятия корпоративного покрова в рамках обычных гражданско-правовых споров. Указываются пути и способы решения проблемы отсутствия единообразия в применении указанного правового механизма, в том числе предлагается закрепить условия применения доктрины в рамках гражданского законодательства.

Ключевые слова: доктрина «снятия корпоративной вуали», ответственность, контролирующие лица, кредитор, злоупотребление правом.

лица, в том числе и от своих участников (членов). Оно оправдано в ограниченном числе случаев, когда подконтрольная организационно-правовая структура используется контролирующим лицом в качестве инструмента для реализации своих собственных интересов без учета интересов зависимого субъекта [1, с. 32].

Также имеет место позиция указывающая, что доктрина «снятия корпоративных покровов» должна ограничиваться случаями прекращения юридических лиц при недостаточности их имущества для удовлетворения требований кредиторов [2, с. 10-11].

Существует диаметрально противоположная позиция, определяющая механизм «снятия корпоративной вуали» как систему юридических средств, обеспечивающих возможность возникновения ответственности у лица, которое эту ответственность не несет в силу действия ограниченной ответственности и автономности корпорации [3, с. 45]. При этом, автором не раскрывается сама система юридических средств, а обозначена лишь цель концепции, что дает право полагать о широком её применении. 
Разнообразие позиций в отношении условий применения доктрины «снятия корпоративной вуали» порождает проблему неопределённости применения данного правого механизма.

При анализе применения механизма снятия корпоративной вуали, необходимо исследовать цели его применения.

Основной целью доктрины снятия корпоративной вуали является восстановление нарушенного права кредиторов путем транспозиции ответственности с юридического лица на контролирующее его лицо В виду злоупотребления контролирующим лицом правами при осуществлении управления юридическим лицом. Это основополагающая цель, для которой и используется доктрина снятия корпоративной вуали.

Указанная цель порождает условия её применения, которые мы и разберем, что и позволит четко сформулировать признаки (условия) применения доктрины снятия корпоративной вуали.

На наш взгляд, существуют три основных условия применения механизма снятия корпоративной вуали.

Первое условие заключается в наличии злоупотребления правом со стороны контролирующего лица при осуществлении управления юридическим лицом. В данном случае в виде злоупотребления следует понимать такое поведение контролирующего лица, которое подменяет волю юридического лица волей контролирующего лица, что приводит de facto к слиянию контролирующего лица и юридического лица.

В данном случае юридическое лицо существует как абстрактный участник гражданских правоотношений, без каких-либо собственных целей, например извлечения прибыли и т.д. Фактически контролирующее лицо прикрывает своё недобросовестное поведение ширмой в виде юридического лица, что позволяет такому контролирующему лицу нарушать права кредиторов и получать за счет этого необоснованную выгоду (имущество или имущественные права).

Наличие такого обязательного условия как злоупотребления правом со стороны контролирующего лица выражено, в первую очередь, существованием принципов: равенства участников гражданских правоотношений, недопустимости произвольного вмешательства кого-либо в частные дела, добросовестности участников гражданских правоотношений и разумность их действий, которые устанавливаются в рамках гражданского законодательства.
Указанные принципы фактически предоставляют защиту от вмешательства в деятельность юридического лица извне, в том числе и кредиторов юридического лица, и перекладывания ответственности с юридического лица на контролирующее лицо.

Как следствие, по мнению автора, для пренебрежения основополагающими принципами гражданского права и вмешательства в юридическое лицо, а также перекладывания ответственности с юридического лица на контролирующее лицо, должно существовать исключительное условие, выражающееся в злоупотреблении правом со стороны контролирующего лица. Только в таком случае возможно отойти от основополагающих принципов гражданского права и стереть границу между юридическим лицом и контролирующем лицом путем возложения ответственности.

Вторым условием является факт наличия нарушенного права кредитора юридического лица. Поскольку в отсутствии факта нарушения права и отсутствует необходимость его защиты путем применения доктрины снятия корпоративной вуали.

Условие наличия нарушенного права вытекает из самой цели доктрины, которая направлена на восстановление нарушенного права кредитора.

И, соответственно, третьим условием является наличие причинно-следственной связи между злоупотреблением правом со стороны контролирующего лица и нарушенным правом кредитора. По мнению автора, факт нарушения прав кредитора должен следовать из факта злоупотребления правом со стороны контролирующего лица. Указанные обстоятельства, в том числе могут доказываться в процессе снятия корпоративной вуали и исследования деятельности юридического лица и влияния контролирующего лица на его действия.

Приведенные автором условия позволяют определить правовые случаи применения доктрины «снятия корпоративной вуали». Следует помнить, что прежде чем применять доктрину и «размывать» границы между юридическим лицом и контролирующим лицом необходимо, чтобы кредитор доказал факт злоупотребления правом со стороны контролирующего лица, либо представил такие доказательства, которые позволили бы усомниться в добросовестности контролирующего лица.

По мнению автора, для вскрытия корпоративного покрова и дальнейшего исследования наличия факта злоупотребления правом со стороны контролирующего лица, суду должно быть достаточно лишь наличия косвенных доказательств, подтверждающих недобросовестное поведение контролирующего лица при 
управлении юридическим лицом. Указанный вывод обосновывается тем обстоятельством, что кредитор ограничен в способах и средствах доказывания, ввиду наличия всё тех же принципов гражданского права, которые указывались ранее, не позволяющих ему самостоятельно собрать достаточно доказательств наличия злоупотребления со стороны контролирующего лица.

Исходя из приведенных условий применения доктрины «снятия корпоративной вуали» необходимо определить границы (направления) применения данного механизма.

Как неоднократно указывалось, доктрина «снятия корпоративной вуали» направлена на защиту интересов кредиторов. Указанное обстоятельство позволяет нам установить фактически два основных направления применения данной доктрины.

Первое направление - это применение доктрины в рамках гражданско-правовых споров, связанных с защитой кредиторами своих прав при применении различных способов защиты права. Например, взыскания убытков, связанных как с договором (заключенным между кредитором и юридическим лицом которым осуществляет управление контролирующее лицо), так и не в рамках договора (без наличия договорных обязательств), или признания сделки недействительной.

По мнению автора, такое направление применения доктрины «снятия корпоративной вуали» обеспечит защиту кредиторов от недобросовестного поведения контролирующих контрагента лиц. Это обусловлено, в первую очередь, отсутствием какой-либо правовой защиты кредиторов в рамках обычных гражданско-правовых споров в случае злоупотребления правами со стороны контролирующего лица.

Противниками данного применения являются ученые, которые указывают, что доктрина должна применяться только в рамках дела о банкротстве, когда организация не может отвечать по своим обязательствам и имеется необходимость устанавливать субсидиарную ответственность в отношении недобросовестных контролирующих лиц. Однако, на наш взгляд, данная позиция является необоснованной, поскольку ограничивает возможность восстановления нарушенного права, а также предоставляет возможность недобросовестному контролирующему лицу уйти от ответственности до момента банкротства юридического лица, либо вовсе на момент банкротства юридического лица будет невозможно установить фактическую недобросовестность ввиду значительного срока или в силу иных обстоятельств.
Таким образом, нет оснований отрицать необходимость применения доктрины «снятия корпоративной ответственности» в рамках обычных гражданско-правовых споров, в случае наличия злоупотребления со стороны контролирующего лица.

Вторым направлением применения доктрины «снятия корпоративной ответственности» является рассмотрение споров в рамках дела о банкротстве.

Это направление применения данного механизма значительно развивается и поддерживается судебной практикой, что отражено в рамках Постановления Пленума Верховного Суда РФ от 21.12.2017 № 53 «О некоторых вопросах, связанных с привлечением контролирующих должника лиц к ответственности при банкротстве», а также поддерживается рядом ученых указанных ранее.

Основным критерием применения данной доктрины в рамках дела о банкротстве при рассмотрении субсидиарной ответственности выступает неформальный подход к рассмотрению споров. Это обстоятельство позволяет судам и сторонам выходить за обычные рамки формального рассмотрения дела, который установлен при рассмотрении гражданско-правовых споров, что позволяет рассматривать спор исходя из широкого круга доказывания.

Однако, как указано выше, нельзя относить механизм «снятия корпоративной вуали» только к рассмотрению споров в рамках дела о банкротстве, поскольку защита нарушенных прав кредиторов должна осуществляться в любой момент, на что, в конечном счете, и направлено гражданское законодательство.

Автор предлагает разработать и закрепить в российской правой системе механизм правовой ответственности контролирующих лиц за злоупотребление правами при управлении юридическим лицом, путем использования доктрины «снятия корпоративной вуали». Что позволит дисциплинировать контролирующих лиц при управлении юридическим лицом, и уменьшить количество случаев злоупотребления правом с их стороны при осуществлении управленческой деятельности.

Основные условия и направления применения механизма вскрытия корпоративного покрова автором рассмотрены и предложены. Необходимо лишь закрепить данные условия и направления применения доктрины «снятия корпоративной вуали» в российской науке и правоприменительной практики, с учетом общих тенденций развития ответственности контролирующих лиц, что даст толчок необходимости закрепления базовых условий применения данной доктрины в российском законодательстве. 


\section{ЛИТЕРАТУРА}

1. Ломакин Д.В. Концепция снятия корпоративного покрова: реализация ее основных положений в действующем законодательстве и проекте изменений Гражданского кодекса РФ // Вестник ВАС РФ. 2012. N9. С. 6-33

2. Гутников 0.В. Юридическая ответственность в корпоративных отношениях // Вестник гражданского права. 2014. N6. T. 14

3. Колонтаевская И.Ф. Проблемы взаимодействия корпоративного права России и зарубежных стран. Доктрина «снятия корпоративной вуали» // Вестник Московского университета имени С.Ю. Витте. Сер. 2: Юридические науки. 2014. N3

○ Кузнецов Андрей Вячеславович ( kuznec3194@gmail.com ).

Журнал «Современная наука: актуальные проблемы теории и практики»

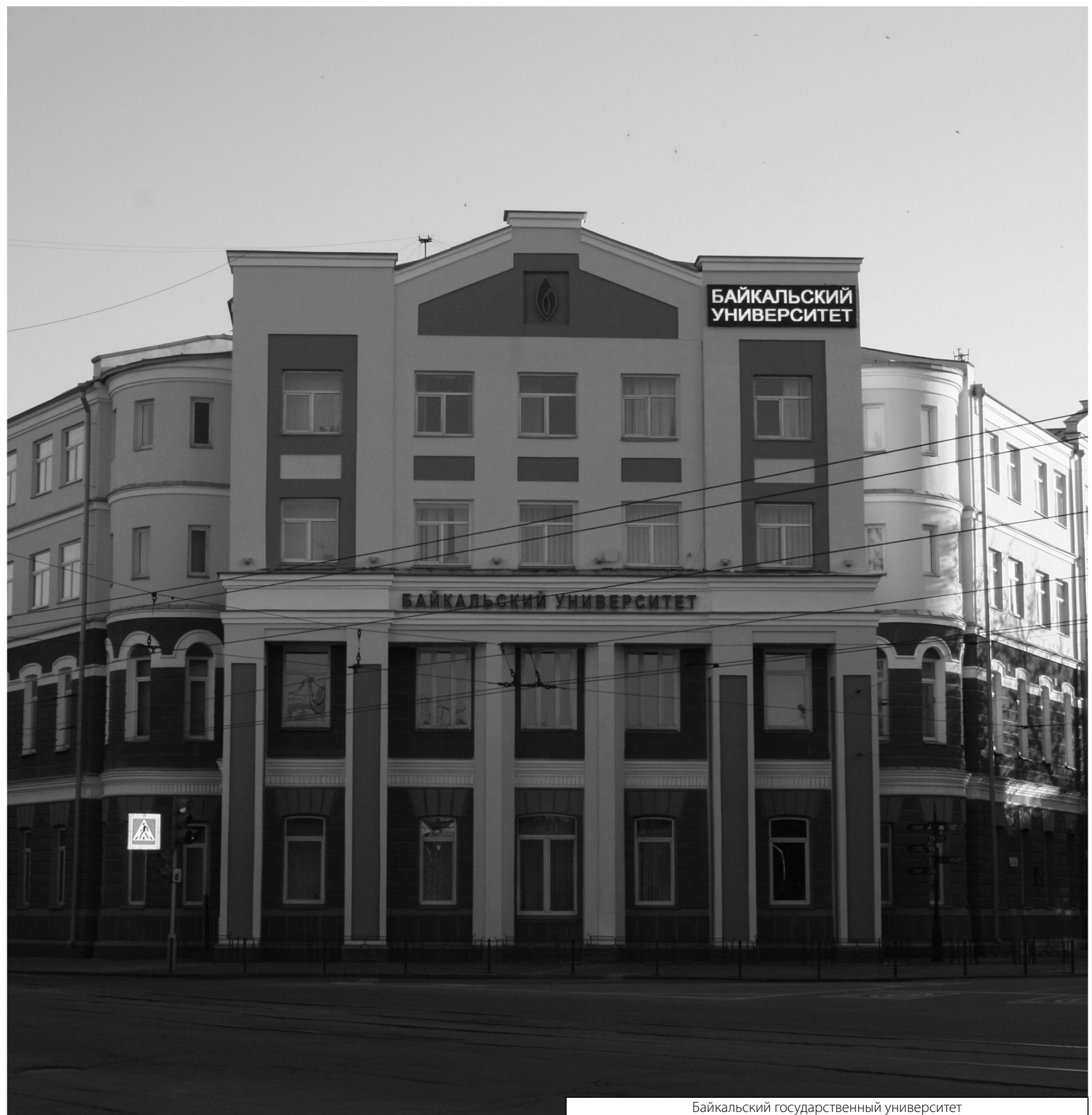

